\title{
Low level of physical activity and sedentary behaviour in elderly: a systematic review of the parameters
}

\section{Baixo nível de atividade física e comportamento sedentário em idosos: uma revisão sistemática dos parâmetros}

\section{Ozeas de Lima Lins-Filho'}

(D) https://orcid.org/0000-0002-9203-6953)

Marisa Moreira Braga ${ }^{2}$

(D) https://orcid.org/0000-0002-8551-4435)

Tatiane Melo de Lima²

(1D) https://orcid.org/0000-0002-6887-0403)

Daniela Karina da Silva Ferreira²

(D) https://orcid.org//0000-0003-1786-7965)

Abstract - Sedentary behavior tends to increase with aging and several studies have focused on analyzing the components which may influence this pattern of behavior. Indirect and direct measuring have been used to determine the relative parameters to this phenomenon while there is no consensus about which parameter should be adopted to conceptualize sedentary behavior, making difficulty to establish comparisons among the studies on this population. The aim of this study was to systematically review the characterization of low level of physical activity and sedentary behavior in studies with older people. Electronic search on Scielo, LILACS, MEDLINE, PubMed, and ISI Web of Knowledge was carried out. Selection of the studies included: original manuscripts, with elderly analyzing sedentary behavior or low-level pf physical activity through direct and indirect measure. Search initially screened 190 manuscripts yielding 10 relevant studies. Questionnaire, self-reported questionnaire and accelerometer were the instruments used in the studies. Sedentary behavior or low level of physical activity was characterized by analyzing sitting time, physical activity on leisure time, counts per minute, engaging in moderate or vigorous intensity during day or performing physical activities with MET $<1.5$. There is no standardization of the parameters adopted to characterize sedentary behavior on studies, generating divergent results and making it difficult to establish comparisons.

Key words: Aging; Leisure activities; Motor activity; Sedentary behavior.

\footnotetext{
Resumo -O comportamento sedentário tende a aumentar com o envelhecimento e vários estudos têm se concentrado em analisar os componentes que podem influenciar esse padrão de comportamento. A mensuração indireta e direta tem sido utilizada para determinar os parâmetros relativos a esse fenômeno, enquanto não há consenso sobre qual parâmetro deve ser adotado para conceituar o comportamento sedentário, dificultando a comparação entre os estudos sobre essa população. O objetivo deste estudo foi revisar sistematicamente a caracterização do baixo nivel de atividade física e comportamento sedentário em estudos com idosos. Pesquisa eletrônica no Scielo, LILACS, MEDLINE, PubMed e ISI Web of Knowledge foi realizada. Seleção dos estudos incluidos: manuscritos originais, com idosos analisando comportamento sedentário ou baixo nivel de atividade física por meio de medida direta e indireta. A pesquisa inicialmente selecionou 190 manuscritos, resultando em 10 estudos relevantes. Questionário, questionário de autorrelato e acelerômetro foram os instrumentos utilizados nos estudos. Comportamento sedentário ou baixo nivel de atividade física foi caracterizado pela análise do tempo sentado, atividade física no lazer, contagens por minuto, intensidade moderada ou vigorosa durante o dia ou atividades físicas com $M E T<1,5$. Não há padronização dos parâmetros adotados para caracterizar o comportamento sedentário em estudos, gerando resultados divergentes e dificultando estabelecimento de comparações.
}

Palavras-chave: Atividade motora; Atividades de lazer; Comportamento sedentário; Envelhecimento.
1 University of Pernambuco. Pronto Socorro Cardiológico de Pernambuco. Recife, PE. Brazil.

2 Federal University of Pernambuco. Postgraduate Program in Physical Education. Recife, PE. Brazil.

Received: December 21, 2018 Accepted: January 08, 2020

How to cite this article Lins-Filho OL, Braga MM, Lima TM, Ferreira DKS. Low level of physical activity and sedentary behaviour in elderly: a systematic review of the parameters. Rev Bras Cineantropom Desempenho Hum 2020, 22:e60810. DOI: http://dx.doi.org/10.1590/19800037.2020v22e60810.

Copyright: This work is licensed under a Creative Commons Attribution 4.0 International License. 


\section{INTRODUCTION}

The population worldwide is becoming old. The aging process is known for being accompanied of some conditions or illnesses, which are not necessarily results of aging; they are mostly triggered by modifiable risk factors related to lifestyle. The individual lifestyle's impact in the health outcomes has been investigated in the past years ${ }^{1}$. The decisions about being sedentary or physically active, eating healthy and sleeping well through the years cause an effect in some characteristics such as the body composition, blood pressure, cognitive function and glycemic levels that, if the choices were not appropriate, might lead to poor health consequences ${ }^{2}$.

Practicing regular physical activity influences positively the health ${ }^{3,4}$. In general, it has been recommended to perform at least 150 minutes of moderate to vigorous physical activity per week to increase physical activity levels and reduce sedentary behavior ${ }^{5}$. It may reduce body fat, blood pressure, glycemic levels and increase muscle and bone mass, preserve functional capacity and memory, ameliorate cognitive function and many others benefits $^{6,7}$. Physical inactivity is associated with the development of many chronic diseases such as hypertension, diabetes, obesity and cancer ${ }^{8,9}$. Furthermore, sedentary behavior is generally characterized by any activity that requires an energetic demand between 1.0 and 1.5 METs in a sitting or reclined position, using the computer or watching television, for example, and it is a risk factor independent of physical activity practice ${ }^{10-12}$, and it is also associated with others unhealthy behaviors and negative health outcomes ${ }^{13-16}$.

Although physical activity has been widely explored in studies aiming to promote a more active lifestyle ${ }^{5,17-19}$, sedentary behavior and low levels of physical activity have emerged in the last years as an important key factor to be considered when discussing about threats against physically active lifestyle on public health scenario ${ }^{20}$. Indeed,therehas been an increase in exposed time to sedentary behavior in the last decade ${ }^{21}$ and prevalence of people who have sedentary behaviors is high between aged people ${ }^{22}$, this may be demonstrated by a report from CDC data in 2005 showing that only $37.7 \%$ of United States population have sedentary behavior or low levels of physical activity ${ }^{23}$. In addition, conversely to physical activity, sedentary behavior is associated to several poor health indexes in elderly people (high blood pressure, obesity and high levels of blood glucose) ${ }^{24,25}$. However, differently from physical activity, studies investigating sedentary behavior or low levels of physical activity in this population have adopted several and different parameters to determine their concepts, including direct measures from electronic devices (accelerometer and pedometers) ${ }^{26-29}$ and indirect from self-report questionnaires and diaries ${ }^{30-32}$, which in turnvarybetween reporting sitting activities more than four hours a day more than five days a weekand daily activities equivalent to $<1.5$ Metabolic Equivalent of Task (MET) ${ }^{33}$. Thus, this lack of standardization between sedentary behavior concepts adopted in the several studies makes hard to establish parameters to compare the reports about this issue. 
Hence, considering there is an increase in time exposed to sedentary behavior in the last decade and the necessity to standardize the characterization of it, that could help to establish more suitable parameters to oppose this phenomenon, the aim of the study was to systematically review and identify the characterization of sedentary behavior and/or low levels of physical activity in original studies with older people.

\section{METHOD}

This study is characterized as a systematic review, previously registered in PROSPERO under the protocol CRD42016038647. Information about sedentary behavior and/or low level of physical activity in elderly were analyzed, previous research was made at COCHRANE database and PROSPERO library to a better definition of the objectives and methods applied and to avoid replicate any finished or ongoing study.

\section{Search strategy}

Original studies - published between January 2006 and July 2018 in English and Portuguese - were examined about interventions with sedentary behavior or low levels of physical activity definitions in elderly. The studies search was realized in these electronic databases: Scielo, LILACS, MEDLINE, PubMed, and ISI Web of Knowledge. The following entry terms were utilized in Portuguese and English respectively: atividade motora motor activity, exercício físico - physical exercise, atividade física - physical activity, idosos - elderly, idosos sedentários - sedentary elderly, comportamento - behavior, comportamento sedentário - sedentary behavior. The Boolean operators "and" and "or" were used to combine the entry terms in the article search. No filters were applied to the search and characteristics differing from the criteria adopted were excluded after the search was completed.

\section{Studies selection}

It was made accordingly the ensuing steps: i) search by "titles" using the entry terms and Boolean operators, applying filters to year of publication, original studies and population age; ii) selecting those presenting "sedentary behavior" or "physical activity" or "exercise" in the title; iii) reading the abstracts of those with samples that included elderly above 60 years; vi) reading full text of the articles selected from the abstracts. Two independent reviewers realized each step and a third reviewer was consulted in case of dispute.

The inclusion criteria were: published original articles from January 2006 to July 2018; studies that included participants above 60 years that presented defined criteria for low level of physical activity and/or sedentary behavior. Case reports and opinion articles were excluded. Furthermore, studies presenting individuals inactive due to serious injuries or in rehabilitation process or diagnosed with specific diseases such as mental disorders were also excluded. 
The following items were obtained from the selected articles: i) title; ii) population; iii) gender iv) objectives; v) study design vi) outcomes vii) sedentary behavior description viii) physical activity description ix) results $\mathrm{x}$ ) instruments. The description about quantitative survey from the Database to the selection of the studies included in this review is present in Figure 1.

\section{Data management}

The results obtained from the research studies were imported into Excel data management software. After analysis, the third reviewer manually removed the duplicates.

\section{Data extraction}

Two reviewers independently extracted data from the selected studies from the Excel data management foundation using a data extraction form. The form was developed considering the characteristics of studies to ensure consistency of this process. In case of disagreement, a third reviewer was consulted. The data extraction used the following categories: Author, Journal, Sample (amount of people studied), Study Design (Observational, Longitudinal, Clinical Trial, Cohort, Prospective Cohort), Instruments (direct or indirect measures), Purpose, Definition of Sedentary Behavior and/or Low-Level Physical Activity, Results and Conclusions.

The primary outcomes were parameters related to low levels of physical activity and sedentary behavior. Sedentary behavior outcomes included objectively measured sedentary behavior or sitting time using accelerometers or pedometers. Self-report sedentary behavior outcomes included time spent watching TV, computer usage, total screen time (TV, computer and phone/iPad use combined) or sitting (travel, relaxing and workplace). Selfreport outcomes of low levels of physical activity included reporting how often they took part of several ranges of physical activity intensities and objectively measuring low levels of physical activity including calculating the intensities of the physical activity bouts.

\section{RESULTS}

The present study shows that there is a high prevalence of sedentary behavior in the elderly population and a predisposition for this behavior to increase with age. The practice of physical activity occurs mostly during daytime and it is more likely to be in a light or moderate intensity. Higher levels of sedentary behavior are associated with poorer physical strength ${ }^{31}$; younger age and lower body mass index may be a predictor of physical behavior $^{32}$. Some educational interventions to change behavior may be effective to this population but yet more experimental studies are needed to verify what interventions are the most effective ${ }^{30}$.

Box 1 presents a summary of the overall characterization of the selected studies, in general, epidemiology and public health were the main scope for the journals, the sample size was between 20 and 7735 elderly, in the 


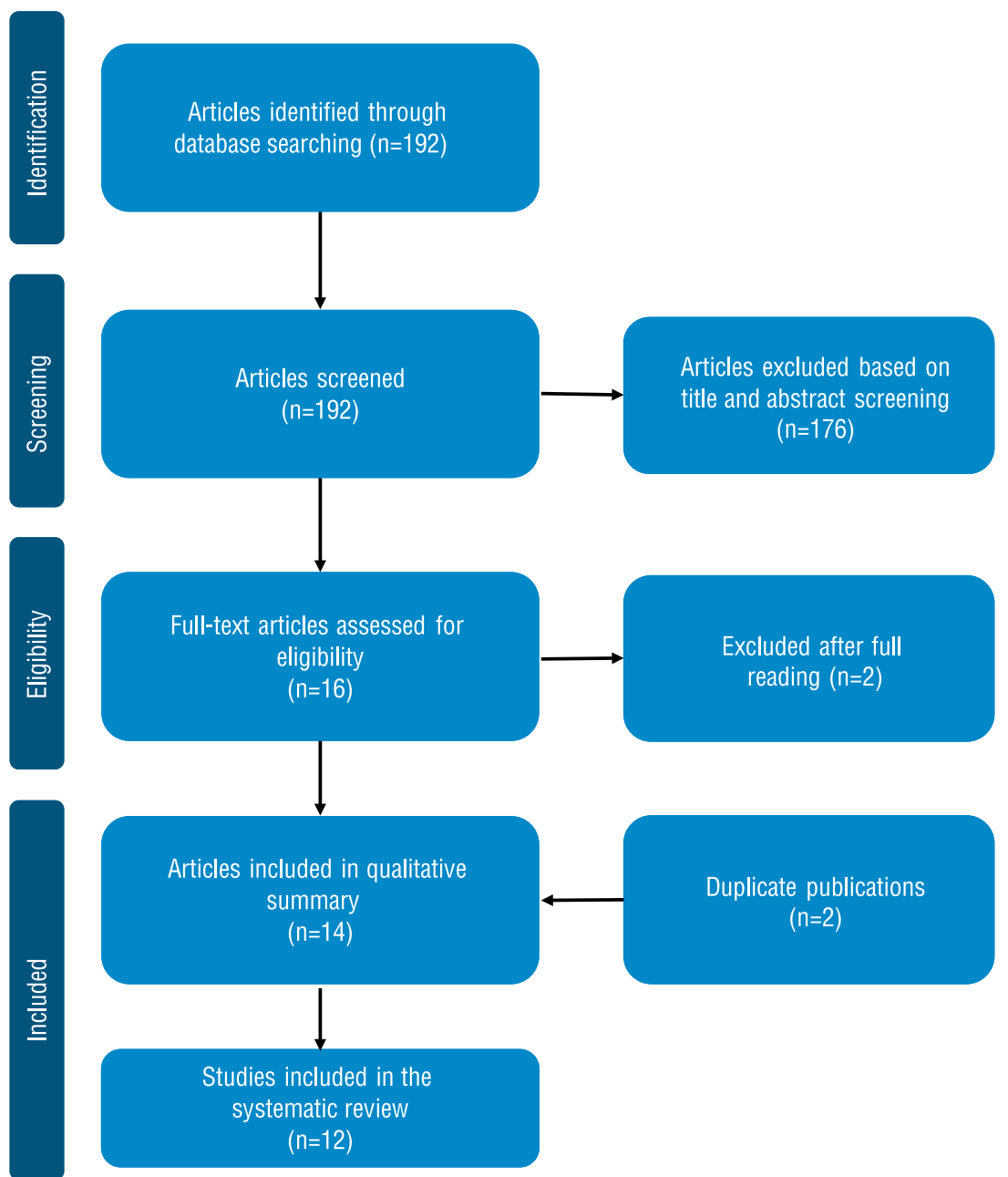

Figure 1. Description about quantitative survey from the Database to the selection of the studies included in this review.

different studies design from observational to experimental (clinical trial), and the questionnaire and accelerometer were the instruments more used.

\section{Interventions}

Only two studies were categorized as clinical trials ${ }^{30,34}$. Hershenberg et al. ${ }^{34}$ evaluated association between the participation of 20 older adults in weekly activities and behavioral outcomes. They carried out pre and post five weeks interventions measures. In another study, Schneider et al. ${ }^{30}$ compared selfreported behavior outcomes over 1 year between three groups of older adults receiving different behavior education treatments. The assessments were performed in three months intervals. Moreover, one study met the inclusion criteria, however it did not describe the parameters adopted to analyze sedentary behavior or low level of physical activity ${ }^{35}$. Furthermore, other studies had different methodological designs that are described in Box 1.

Box 2 summarizes the descriptions about the studies definition of sedentarybehavior or physical activity, to teach change behavior, different strategies were used in the definition variable was referred the amount, duration, intensity and/or type for physical activity. 
Box 1. Characterization studies, aboutlow levels of physical activity and/or sedentary behavior in elderly, classified for journal, sample, study design and instruments, published between $2006-2018$.

\begin{tabular}{|c|c|c|c|c|}
\hline Author & Journal & Sample (Country of study) & Study Design & Instruments \\
\hline Brazão et al. ${ }^{36}$ & Motriz & $\begin{array}{l}46 \text { elderly men and } 33 \text { elderly } \\
\text { female (Brazil) }\end{array}$ & Observational study & Questionnaire \\
\hline Schneider et $\mathrm{a}^{30}$ & Age and Ageing & 342 elderly (United States) & Longitudinal study & Questionnaire \\
\hline Lord et al. ${ }^{26}$ & Age and Ageing & $\begin{array}{l}56 \text { individuals with an average } \\
\text { age of } 79.9 \text { (United Kingdom) }\end{array}$ & $\begin{array}{l}\text { Randomized interven- } \\
\text { tion }\end{array}$ & Accelerometer \\
\hline Hamer and Stamatakis ${ }^{31}$ & Plos One & $\begin{array}{l}2845 \text { elderly men and } 3383 \\
\text { elderly women (England) }\end{array}$ & Cohort study & Questionnaire \\
\hline Anokye and Stamatakis ${ }^{27}$ & $\begin{array}{l}\text { BMC Research } \\
\text { Notes }\end{array}$ & $\begin{array}{l}4507 \text { adults over } 16 \text { years aver- } \\
\text { age age } 51.7 \pm 18 \text { (England) }\end{array}$ & Observational study & Accelerometer \\
\hline Blodgett et al. ${ }^{28}$ & Maturitas & $\begin{array}{l}3146 \text { individuals above } 50 \text { years } \\
\text { (United States) }\end{array}$ & Cohort study & Accelerometer \\
\hline Smith et al. ${ }^{29}$ & BMJ Open. & $\begin{array}{l}5186 \text { men e } 6205 \text { women born } \\
\text { before March } 1952 \text { (England) }\end{array}$ & Longitudinal study & Accelerometer \\
\hline Sartiniet al. ${ }^{33}$ & BMC Public Health & $\begin{array}{l}7735 \text { elderly men (United } \\
\text { Kingdom) }\end{array}$ & Prospective cohort & Accelerometer \\
\hline Heseltine et al. ${ }^{32}$ & $\begin{array}{l}\text { BMC Family } \\
\text { Practice }\end{array}$ & $\begin{array}{l}1104 \text { elderly above } 65 \text { years } \\
\text { (United Kingdom) }\end{array}$ & Clinical trial & $\begin{array}{l}\text { Self-report Question- } \\
\text { naire }\end{array}$ \\
\hline Hershenberg ${ }^{34}$ & BMC Public Health & $\begin{array}{l}17 \text { elderly men and } 3 \text { elderly } \\
\text { women (United States) }\end{array}$ & Clinical trial & Questionnaire \\
\hline Loginov et al. ${ }^{37}$ & Adv Gerontol & $\begin{array}{l}295 \text { elderly, } 102 \text { men and } 193 \\
\text { women (Russia) }\end{array}$ & Observational study & Questionnaire \\
\hline Aro et al. ${ }^{38}$ & $\begin{array}{l}\text { Afr. j. prim. health } \\
\text { care fam. med. }\end{array}$ & $\begin{array}{l}139 \text { elderly above } 60 \text { years of } \\
\text { residential care facility (South } \\
\text { Africa) }\end{array}$ & Cross-sectional study & Questionnaire \\
\hline
\end{tabular}

Box 2. Description of the studies, about low levels of physical activity and/or sedentary behavior in elderly, for definition of Sedentary Behavior and/or level Physical Activity, published between 2006-2018.

\begin{tabular}{|c|c|}
\hline Author & Definition of Sedentary Behavior/Physical Activity \\
\hline Brazão et al. ${ }^{36}$ & $\begin{array}{l}\text { PA regular practice on leisure time assessed through a question with five alternatives to classify sub- } \\
\text { jects into one of the five behavior changing stages }\end{array}$ \\
\hline Schneider et al. ${ }^{30}$ & $\begin{array}{l}\text { PA how Hours of activity per week were computed by dividing the product of number of times per } \\
\text { month and minutes each time by } 60 \mathrm{~min} / \mathrm{h} \text { and then by four weeks/month }\end{array}$ \\
\hline Lord et al. ${ }^{26}$ & $\begin{array}{l}\text { PA how Gini index (bout lengths of periods of rest or bouts characterized by their duration and cadence } \\
\text { - activities) }\end{array}$ \\
\hline Hamer and Stamatakis ${ }^{31}$ & $\begin{array}{l}\text { SB how average daily time spent watching TV/internet. For PA Participants were asked how often they } \\
\text { took part in three different types of PA: vigorous, moderate- and low- intensity PA }\end{array}$ \\
\hline Anokye and Stamatakis ${ }^{27}$ & $\begin{array}{l}\text { SB defined as the number of daily minutes with a minutely accelerometer count of }<200 \text { counts/minute. } \\
\text { MVPA was defined as a minutely count of } \geq 2020 \text { counts/minute }\end{array}$ \\
\hline Blodgett et al. ${ }^{28}$ & $\begin{array}{l}\text { SB defined as } 0-100 \text { counts/min on the ActiGraph Accelerometer. Light (101-2020 counts/min), mod- } \\
\text { erate (2021-5999 counts/min) and vigorous }(6000+\text { counts/min) activity }\end{array}$ \\
\hline Smith et al. ${ }^{29}$ & $\begin{array}{l}\text { Participants were asked how often they took part in vigorous-intensity, moderate-intensity and low- } \\
\text { intensity PA, using prompt cards. At each time point, PA was classified as: inactive; only light activity } \\
\text { at least once a week (but no moderate or vigorous); moderate activity at least once a week (but no } \\
\text { vigorous), and vigorous activity at least once a week }\end{array}$ \\
\hline Sartiniet al. ${ }^{33}$ & $\begin{array}{l}\text { The measure used to classify behavior was counts per minute. }<100 \mathrm{CPM} \text { for SB }(<1.5 \text { Metabolic } \\
\text { Equivalent of Task, MET). Another measure of SB was calculated: number of sedentary bouts of at least } \\
1 \mathrm{~h} \text { (a period of } 60 \text { or more consecutive minutes where the accelerometer registers }<100 \mathrm{CPM})\end{array}$ \\
\hline Heseltine et al..$^{32}$ & SB was defined as sitting activities for more than four hours in more than five days a week \\
\hline Hershenberget al. ${ }^{34}$ & There were no description of SB or PA \\
\hline Loginov et al. ${ }^{37}$ & PA: Iow-intensity, moderate-intensity, high-intensity; SB how average daily time spent in min/week \\
\hline Aro et al. ${ }^{38}$ & $\begin{array}{l}\text { PA were grouped into three intensity categories as defined (low, medium and high) and regular exercise } \\
\text { is engagement in exercise for at least } 150 \text { min per week; no description of SB. }\end{array}$ \\
\hline
\end{tabular}

Note. ${ }^{*} \mathrm{PA}=$ Physical Activity; $\mathrm{SB}=$ Sedentary behavior; MVPA = Moderate to vigorous physical activity; MET = Metabolic Equivalent of Task; CPM = Counting per minute 
Information about featuring the purpose of the studies, to test hypothesis about sedentary behavior or physical activity and variables of the health conditions, frailty or fitness, presented the different results and conclusion were summarized in the Box 3.

Box 3. Summary of the studies, about low levels of physical activity and/or sedentary behavior in elderly, classified for purpose, results and conclusions, published between $2006-2018$.

\begin{tabular}{|c|c|c|c|}
\hline Author & Purpose & Results & Conclusions \\
\hline Brazão et al. ${ }^{36}$ & $\begin{array}{l}\text { To analyze the prevalence of be- } \\
\text { havior, change stages and the main } \\
\text { barriers or reasons that prevent or } \\
\text { difficult the regular PA practice }\end{array}$ & $\begin{array}{l}64,6 \% \text { of the elderly in the study did } \\
\text { not practice PA regularly }\end{array}$ & $\begin{array}{l}\text { The majority of the elderly is on } \\
\text { pre-contemplation stage and the } \\
\text { sex does not influence on the } \\
\text { perceived barriers }\end{array}$ \\
\hline Schneider et al. ${ }^{30}$ & $\begin{array}{l}\text { To teach older adults to recognize } \\
\text { and modify their thoughts, or inter- } \\
\text { pretation, about exercise }\end{array}$ & $\begin{array}{l}\text { Therapy and educational groups } \\
\text { increased their strengthening exer- } \\
\text { cises over time }\end{array}$ & $\begin{array}{l}\text { Although the therapy group } \\
\text { increased their strengthening } \\
\text { exercises, they decreased their } \\
\text { 6-minutes walking distance }\end{array}$ \\
\hline Lord et al. ${ }^{26}$ & $\begin{array}{l}\text { To quantify and describe habitual } \\
\text { active and SB in older }\end{array}$ & $\begin{array}{l}\text { Walking behavior, SB and postural } \\
\text { transitions accounted for total vari- } \\
\text { ance of the model }\end{array}$ & $\begin{array}{l}\text { Walking, sedentary and transitions } \\
\text { behavior explains together daily } \\
\text { functions }\end{array}$ \\
\hline $\begin{array}{l}\text { Hamer and } \\
\text { Stamatakis }{ }^{31}\end{array}$ & $\begin{array}{l}\text { To test the overall hypothesis that } \\
\text { excess screen-based SB is inversely } \\
\text { associated with muscle strength }\end{array}$ & $\begin{array}{l}\text { Participants who viewed more TV } \\
\text { had a lower strength than who } \\
\text { viewed less TV }\end{array}$ & $\begin{array}{l}\text { In elderly, association between } \\
\text { sedentary activities and physical } \\
\text { function are linked to context (TV } \\
\text { viewing time) }\end{array}$ \\
\hline $\begin{array}{l}\text { Anokye and } \\
\text { Stamatakis }{ }^{27}\end{array}$ & $\begin{array}{l}\text { To test the interdependent nature } \\
\text { of PA and SB and to compare two } \\
\text { different modelling frameworks, } \\
\text { namely independent equations us- } \\
\text { ing objectively-assessed PA and SB }\end{array}$ & $\begin{array}{l}\text { People spend } 47 \text { minutes undertak- } \\
\text { ing SB per valid day; older individu- } \\
\text { als, were associated with lower level } \\
\text { of MVPA; SB was positively correlat- } \\
\text { ed with age, and the MVPA equation } \\
\text { was found to be correlated with SB's } \\
\text { equation ( } r=-0.156 ; p<0.001)\end{array}$ & $\begin{array}{l}\text { Studies with accelerometers sug- } \\
\text { gest that accounting for the inde- } \\
\text { pendent nature of physical activity } \\
\text { and SB results in more efficient } \\
\text { estimates }\end{array}$ \\
\hline Smith et al. ${ }^{29}$ & $\begin{array}{l}\text { To investigate the stability of the } \\
\text { activity about a 10-year-period }\end{array}$ & $\begin{array}{l}\text { There was a trend in decreasing } \\
\text { levels of activity and reduction in } \\
\text { vigorous activity over time }\end{array}$ & $\begin{array}{l}\text { Time spent in vigorous activities } \\
\text { decreased over time and several } \\
\text { sociodemographic factors were } \\
\text { associated with chance of being } \\
\text { persistently active }\end{array}$ \\
\hline Sartiniet al. ${ }^{33}$ & $\begin{array}{l}\text { To investigate diurnal variations in } \\
\text { measured Light PA, Moderate-to- } \\
\text { Vigorous PA and SB is modified by } \\
\text { key demographic, health status and } \\
\text { health conditions }\end{array}$ & $\begin{array}{l}\text { Time spent with SB was lower in the } \\
\text { morning meanwhile and increased } \\
\text { throughout the day }\end{array}$ & $\begin{array}{l}\text { Levels of moderate-vigorous PA } \\
\text { are higher in the morning and } \\
\text { decreases during the day }\end{array}$ \\
\hline Heseltine et al. ${ }^{32}$ & $\begin{array}{l}\text { To explore the SB in elderly partici- } \\
\text { pating in an intervention test with } \\
\text { exercise and to investigate which } \\
\text { health, demographic and social fac- } \\
\text { tors are associated with SB }\end{array}$ & $\begin{array}{l}\text { The probability of being categorized } \\
\text { as sedentary augmented with an } \\
\text { abnormal BMI. Participants report- } \\
\text { ing better physical health had lower } \\
\text { odds ratio of being sedentary }\end{array}$ & $\begin{array}{l}\text { In general, older participants will } \\
\text { respond positively to join in an } \\
\text { exercise group }\end{array}$ \\
\hline $\begin{array}{l}\text { Hershenberget } \\
\text { al. }^{34}\end{array}$ & $\begin{array}{l}\text { To investigate the participation in } \\
\text { game weekly activities in the treat- } \\
\text { ment outcomes }\end{array}$ & $\begin{array}{l}\text { Behavioral activation was associ- } \\
\text { ated to a reduction in depressive } \\
\text { symptoms. Participant's total } \\
\text { number of reported activities was } \\
\text { not associated with their improve- } \\
\text { ments in symptoms }\end{array}$ & $\begin{array}{l}\text { Independent of the specific type or } \\
\text { total mount, activation activities } \\
\text { may be associated with improve- } \\
\text { ments of symptomatology }\end{array}$ \\
\hline Loginov et al. ${ }^{37}$ & $\begin{array}{l}\text { To establish gender-specific } \\
\text { characteristics of PA and sedentary } \\
\text { behavior in elderly }\end{array}$ & $\begin{array}{l}\text { Detected that more energy is spent } \\
\text { on the housework and PA in the coun- } \\
\text { try (moderate-intensity PA for women } \\
\text { and high-intensity one for men) }\end{array}$ & $\begin{array}{l}\text { Showed no statistically significant } \\
\text { gender-specific differences in gen- } \\
\text { eral PA. SB is more popular among } \\
\text { men rather than women }\end{array}$ \\
\hline Aro et al. ${ }^{38}$ & $\begin{array}{l}\text { To explore socio-demographic and } \\
\text { clinical factors that are associated } \\
\text { with regular exercise }\end{array}$ & $\begin{array}{l}\text { Participant's knowledge of the } \\
\text { benefits of regular physical activities, } \\
\text { opportunities to socialize, encourage- } \\
\text { ment by health care workers and avail- } \\
\text { ability of exercise facilities and trainers } \\
\text { promote regular physical exercise. } \\
\end{array}$ & $\begin{array}{l}\text { Significant proportion of the elderly } \\
\text { do not engage in regular physi- } \\
\text { cal exercise, and this behavior is } \\
\text { influenced by personal health status } \\
\text { and systems-related motivators and } \\
\text { barriers. }\end{array}$ \\
\hline
\end{tabular}

Note. ${ }^{*} \mathrm{PA}=$ Physical Activity; $\mathrm{SB}=$ Sedentary behavior; $\mathrm{MVPA}=$ Moderate to vigorous physical activity; $\mathrm{MET}=$ Metabolic Equivalent of Task; CPM = Counting per minute; $\mathrm{BMI}=$ Body Mass Index 


\section{DISCUSSION}

The purpose of this systematic review was to summarize the literature discussing sedentary behavior and low levels of physical activity in elderly. Several studies were considered, which presented various definitions for sedentary behavior and/or low levels of physical activity. Different methods of characterizing sedentary behavior included reporting sitting activities more than four hours a day more than five days a week ${ }^{32}$, classifying as inactive accordingly prompt cards, counting per minute (<100 CPM) for sedentary behavior equivalent to $<1.5$ Metabolic Equivalent of Task $(\mathrm{MET})^{33}$, number of sedentary bouts equivalent to $<100 \mathrm{CPM}$ counted through accelerometer and the number of daily minutes with a minutely accelerometer count of $<200$ counts/minute ${ }^{27}$. The characterization of low levels of physical activity included reporting how often they took part of a vigorous-intensity physical activity, moderate intensity and low intensity through prompt cards with different pictures of the activities to help ${ }^{31}$, classifying physical activity at light activity (1.5-3.0 MET) and moderate to vigorous physical activity $(\geq 3 \mathrm{MET})^{33}$, calculating moderate to vigorous physical activity bouts of at least 10 minutes $^{33}$. Moreover, counting hours of activity per week was another method used to try to determine low levels of physical activity ${ }^{30}$. As reported, the methods included self-reporting and direct measures of physical activity through accelerometer.

Based on this assessment, the studies provide inconsistent evidences of how sedentary behavior and low levels of physical activity in elderly are being characterized. Furthermore, there is no standardization of the sedentary behavior and level of physical activity assessment methods. Thus, to compare these results and variables becomes a difficult and maybe inaccurate task.

In this sense, this lack of standardization resulted in several outcomes related to sedentary behavior and level of physical activity. For example, Smith et al. ${ }^{29}$ found, after investigate physical activity during 10 years, that age was associated with a lower likelihood of being physically active and physical activity levels decreased over time ${ }^{29}$ whereas another study verified that aging was associated to lower levels of moderate to vigorous physical activity ${ }^{27}$. However, while the former study used prompt cards to help individuals to self-report physical activity levels, second classified subjects in sedentary or having low level of physical activity using an accelerometer. Additionally, Heseltine et al. ${ }^{32}$ adopted a questionnaire to classify sedentary behavior thorough (defined as sitting activities for more than four hours in more than five days a week) and verified that sedentary behavior was not associated to age ${ }^{32}$. Similarly, a previous study, using an accelerometer, it was found that age was not a predictor for sedentary behavior ${ }^{26}$.

The conflicting results may be due, in part, to the different nature of the various instruments adopted to classify the sedentary behavior. Indeed, a previous study compared sedentary behavior indexes assessed through questionnaire and accelerometer ${ }^{39}$. It reported a small correlation with 
substantial variability between the methods and a low agreement between self-reported sitting category and objective sedentary time. These findings reinforce our conclusions indicating that different methods to assess sedentary behavior may promote divergent results.

Thereby, the different parameters adopted to classify sedentary behavior and low levels of physical activity may partially explain the contradictory results presented from the several studies in this population, which in turn, does not allow making comparisons between the findings. Additionally, the distinct instruments used in the investigations are another point to be considered. Direct measurement instruments (accelerometer and pedometer) used in some of the studies ${ }^{26-29}$ give a more reliable measure about sedentary behavior patterns than indirect measurement instruments (questionnaire and self-reports) although the second are more viable to apply in larger studies ${ }^{30-32}$.

To the best of our knowledge, there were no studies focusing on reviewing sedentary behavior or low levels of physical activity in older people. A preliminary study reviewed the most effective behavior changing techniques to reduce sedentary behavior or increase level of physical activity in middle-aged adults ${ }^{40}$. However, as reported, the review was carried out with adults younger than 60 years old, which in turn did not allow us to make any comparisons between results.

Additionally, inactive people must be a key target since they present a higher risk of presenting negative health outcomes. As reported previously, inactive elderly has not been targeted of studies focusing on their sedentary behavior of low levels of physical activity and the several studies that analyzed sedentary behavior or levels of physical activity adopted different methods to determine these outcomes and designs. Moreover, the objectives differed between each study.

Finally, this review was the first to evaluate sedentary behavior and levels of physical activity in older people through originals studies, strengthening the need of more works targeting the development and evaluation of the interventions to increase levels of physical activity, reduce sedentary behavior and standardize the parameters of sedentary behavior assessment.

\section{CONCLUSION}

The results of the current study showed that there is no standardized method to determine sedentary behavior and/or low level of physical activity between the original studies discussed about these two variables and given the same outcomes, different instruments may elicit divergent results. Additionally, it is possible to emphasize the importance of the regular practice of moderate physical activities and the reduction of the sedentary behavior to improve physical functions and promote the health of the elderly. Thus, more studies are necessary aiming to standardize the methods to allow making comparisons about outcomes related to sedentary behavior and low level of physical activity in elderly. 


\section{COMPLIANCE WITH ETHICAL STANDARDS}

\section{Funding}

This research did not receive any specific grant from funding agencies in the public, commercial, or not-for-profit sectors. This study was funded by the authors.

\section{Ethical approval}

The article was written in accordance with standards set by the Declaration of Helsinki.

\section{Conflict of interest statement}

The authors have no conflict of interests to declare.

\section{Author Contributions}

Conceived and designed the experiments: DKSF;OLLF. Performed the experiments: MMB;TML;OLLF Analyzed the data: OLLF. Contributed reagents/materials/analysis tools:MMB; TML. Wrote the paper:DKSF;OLLF; MMB.

\section{REFERENCES}

1. Baillot A, Romain AJ, Boisvert-Vigneault K, Audet M, Baillargeon JP, Dionne IJ, et al. Effects of lifestyle interventions that include a physical activity component in class II and III obese individuals: a systematic review and meta-analysis. PLoS One 2015;10(4):e0119017.

2. Lee IM, Shiroma E, Kamada M. Accelerometer-assessed Physical Activity, Sedentary Behavior And All-cause Mortality In The Women's Health Study: 1990 Board \#142 June 2, 3: 30 PM - 5: 00 PM. Med Sci Sports Exerc 2016;48(5 Suppl 1):554.

3. Haskell WL, Lee IM, Pate RR, Powell KE, Blair SN, Franklin BA, et al. Physical activity and public health: updated recommendation for adults from the American College of Sports Medicine and the American Heart Association. Med Sci Sports Exerc 2007;39(8):1423-34.

4. O'Donovan G, Blazevich AJ, Boreham C, Cooper AR, Crank H, Ekelund U, et al. The ABC of Physical Activity for Health: a consensus statement from the British Association of Sport and Exercise Sciences. J Sports Sci 2010;28(6):573-91.

5. Garber CE, Blissmer B, Deschenes MR, Franklin BA, Lamonte MJ, Lee IM, et al. American College of Sports Medicine position stand. Quantity and quality of exercise for developing and maintaining cardiorespiratory, musculoskeletal, and neuromotor fitness in apparently healthy adults: guidance for prescribing exercise. Med Sci Sports Exerc 2011;43(7):1334-59.

6. Chodzko-Zajko WJ, Proctor DN, Fiatarone Singh MA, Minson CT, Nigg CR, Salem GJ, et al. American College of Sports Medicine position stand. Exercise and physical activity for older adults. Med Sci Sports Exerc 2009;41(7):1510-30.

7. Thompson PD, Arena R, Riebe D, Pescatello LS. ACSM's new preparticipation health screening recommendations from ACSM's guidelines for exercise testing and prescription, ninth edition. Curr Sports Med Rep 2013;12(4):215-7.

8. Booth FW, Roberts CK, Laye MJ. Lack of exercise is a major cause of chronic diseases. Compr Physiol 2012;2(2):1143-211.

9. Booth FW, Laye MJ, Roberts MD. Lifetime sedentary living accelerates some aspects of secondary aging. J Appl Physiol (1985) 2011;111(5):1497-504. 
10. Mansoubi M, Pearson N, Clemes SA, Biddle SJ, Bodicoat DH, Tolfrey K, et al. Energy expenditure during common sitting and standing tasks: examining the 1.5 MET definition of sedentary behaviour. BMC Public Health 2015;15:516.

11. Copeland JL, Esliger DW. Accelerometer assessment of physical activity in active, healthy older adults. J Aging Phys Act 2009;17(1):17-30.

12. Ainsworth BE, Haskell WL, Herrmann SD, Meckes N, Bassett DR, Jr., TudorLocke C, et al. 2011 Compendium of Physical Activities: a second update of codes and MET values. Med Sci Sports Exerc 2011;43(8):1575-81.

13. Rezende LF, Rodrigues Lopes M, Rey-Lopez JP, Matsudo VK, Luiz Odo C. Sedentary behavior and health outcomes: an overview of systematic reviews. PLoS One 2014;9(8):e105620.

14. Lynch BM. Sedentary behavior and cancer: a systematic review of the literature and proposed biological mechanisms. Cancer Epidemiol Biomarkers Pre 2010;19(11):2691-709..

15. Grontved A, Hu FB. Television viewing and risk of type 2 diabetes, cardiovascular disease, and all-cause mortality: a meta-analysis. JAMA 2011;305(23):2448-55.

16. van Uffelen JG, Wong J, Chau JY, van der Ploeg HP, Riphagen I, Gilson ND, et al. Occupational sitting and health risks: a systematic review. Am J Prev Med 2010;39(4):379-88.

17. Gonzalez-Gross M, Melendez A. Sedentarism, active lifestyle and sport: Impact on health and obesity prevention. Nutr Hosp 2013;28 Suppl 5:89-98.

18. Blair SN, Kohl HW, Gordon NF, Paffenbarger RS, Jr. How much physical activity is good for health? Annu Rev Public Health 1992;13:99-126.

19. Lakka TA, Bouchard C. Physical activity, obesity and cardiovascular diseases. Handb Exp Pharmacol 2005(170):137-63.

20. Katzmarzyk PT. Physical activity, sedentary behavior, and health: paradigm paralysis or paradigm shift? Diabetes 2010;59(11):2717-25.

21. Matthews CE, George SM, Moore SC, Bowles HR, Blair A, Park Y, et al. Amount of time spent in sedentary behaviors and cause-specific mortality in US adults. Am J Clin Nutr 2012;95(2):437-45.

22. Harvey JA, Chastin SF, Skelton DA. Prevalence of sedentary behavior in older adults: a systematic review. Int J Environ Res Public Health 2013;10(12):6645-61.

23. World Health Organization. World health statistics 2016: monitoring health for the SDGs, sustainable development goals. Geneva: World Health Organization, 2016.

24. Richardson CR, Kriska AM, Lantz PM, Hayward RA. Physical activity and mortality across cardiovascular disease risk groups. Med Sci Sports Exerc 2004;36(11):1923-9.

25. Warren TY, Barry V, Hooker SP, Sui X, Church TS, Blair SN. Sedentary behaviors increase risk of cardiovascular disease mortality in men. Med Sci Sports Exerc 2010;42(5):879-85.

26. Lord S, Chastin SF, McInnes L, Little L, Briggs P, Rochester L. Exploring patterns of daily physical and sedentary behaviour in community-dwelling older adults. Age Ageing 2011;40(2):205-10.

27. Anokye NK, Stamatakis E. Different conceptual constructs for modelling sedentary behaviour and physical activity: the impact on the correlates of behaviour. BMC Res Notes 2014;7:921.

28. Blodgett J, Theou O, Kirkland S, Andreou P, Rockwood K. The association between sedentary behaviour, moderate-vigorous physical activity and frailty in NHANES cohorts. Maturitas 2015;80(2):187-91.

29. Smith L, Gardner B, Fisher A, Hamer M. Patterns and correlates of physical activity behaviour over 10 years in older adults: prospective analyses from the English Longitudinal Study of Ageing. BMJ Open 2015;5(4):e007423.

30. Schneider JK, Cook JH, Luke DA. Unexpected effects of cognitive-behavioural therapy on self-reported exercise behaviour and functional outcomes in older adults. Age Ageing 2011;40(2):163-8. 
31. Hamer M, Stamatakis E. Screen-based sedentary behavior, physical activity, and muscle strength in the English longitudinal study of ageing. PLoS One 2013;8(6):e66222.

32. Heseltine R, Skelton DA, Kendrick D, Morris RW, Griffin M, Haworth D, et al. "Keeping Moving": factors associated with sedentary behaviour among older people recruited to an exercise promotion trial in general practice. BMC Family Practice 2015;16(1):1-9.

33. Sartini C, Wannamethee SG, Iliffe S, Morris RW, Ash S, Lennon L, et al. Diurnal patterns of objectively measured physical activity and sedentary behaviour in older men. BMC Public Health 2015;15:609.

34. Hershenberg R, Paulson D, Gros DF, Acierno R. Does Amount and Type of Activity Matter in Behavioral Activation? A Preliminary Investigation of the Relationship between Pleasant, Functional, and Social Activities and Outcome. Behav Cogn Psychother 2015;43(4):396-411.

35. Sjogren P, Fisher R, Kallings L, Svenson U, Roos G, Hellenius ML. Stand up for health--avoiding sedentary behaviour might lengthen your telomeres: secondary outcomes from a physical activity RCT in older people. Br J Sports Med 2014;48(19):1407-9.

36. Brazão MC, Hirayama MS, Gobbi S, Nascimento CMC, Roseguini AZ. Estágios de mudança de comportamento e barreiras percebidas à prática de atividade física em idosos residentes em uma cidade de médio porte do Brasil. Motriz 2009;15(45):759-67.

37. Loginov SI, Malkov MN, Nikolayev AY. Gender-specific manifestations of daily physical activity and sedentary behaviour in elderly people of Surgut. Adv Gerontol 2017;30(4):573-578.

38. Aro AA, Agbo S, Omole OB. Factors influencing regular physical exercise among the elderly in residential care facilities in a South African health district. Afr J Prim Health Care Fam Med 2018;10(1):e1-e6.

39. Gilbert AL, Lee J, Ma M, Semanik PA, DiPietro L, Dunlop DD, et al. Comparison of Subjective and Objective Measures of Sedentary Behavior Using the Yale Physical Activity Survey and Accelerometry in Patients With Rheumatoid Arthritis. J Phys Act Health 2016;13(4):371-6.

40. Howlett N, Trivedi D, Troop NA, Marie Chater A. What are the most effective behaviour change techniques to promote physical activity and/or reduce sedentary behaviour in inactive adults? A systematic review protocol. BMJ Open 2015;5(8).

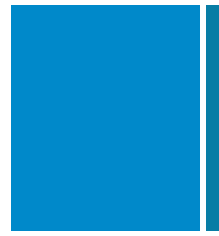

Corresponding author

Daniela Karina da Silva Ferreira

Departament of Physical Education- CCS/UFPE

Av. Professor Moraes Rego, 1235

University City, Recife-PE, Brasil

CEP:50670-901

email: danielakarina@hotmail.com 